Apidologie, 1986, 17 (1), 73-76

RAPID COMMUNICATION

\title{
THE EFFECT OF AN INSECT CHITIN SYNTHESIS INHIBITOR ON HONEY BEES
}

\author{
E.W. HERBERT, Jr. *, R.J. ARGAUER * and H. SHIMANUKI * \\ U.S. Department of Agriculture, Agricultural Research Service \\ *Bioenvironmental Bee Laboratory, Beltsville, MD 20705 \\ * Analytical Chemistry Laboratory, Beltsville, MD 20705
}

\section{SUMMARY}

An insect chitin synthesis inhibitor, BAY SIR 8514, was shown to disrupt brood production in both caged and free-flying colonies of honey bees. Brood rearing was temporarily terminated for a period of 2-3 weeks depending on the level of BAY SIR. Normal brood production resumed after the treatment was terminated. This treatment may provide some control against the parasitic bee mite, Varroa jacobsomi, which only reproduces in sealed brood cells containing older larvae or pupae.

\section{INTRODUCTION}

The Africanized honey bee (Apis mellifera scutellata) was projected to spread through Central America and arrive in Texas around 1990 (TAYLoR, 1977). However, this species was recently found in a feral colony near Bakersfield, California, and this colony was shown to be Africanized. Fortunately, the parasitic bee mite, Varroa jacobsoni which infests the Africanized honey bees in other countries, was not detected in any of the bee samples from California.

Means to control $V$. jacobsoni have not been successful. One biological control method being utilized on a limited scale requires the removal of sealed brood during the active brood rearing season. As most of the mites stay on the brood, this method can reduce mite populations from $80 \%$ up to $98 \%$ (RITTER, 1981). However, this procedure is time consuming, especially if the procedure is repeated several times. 
We report here the preliminary results of a study which suggest a possible alternative method for controlling honey bee mites. BAY SIR $8514^{\circledR}$ (2-chloro-N[[(4-trifluoromethoxyphenyl) amino] carbonyl] benzamide), an insect chitin synthesis inhibitor, was fed to both caged and free-flying colonies of honey bees.

\section{MATERIALS AND METHODS}

Small nuclei containing approximately 4,000 newly emerged bees were confined in $2 \times 2 \times 2 \mathrm{~m}$ cages and offered a pollen substitute (Herbert and ShimanuKI, 1980) containing 1, 10,50 or $100 \mathrm{ppm}(\mathrm{mg} / \mathrm{kg})$ BAY SIR for up to 12 weeks. Ethanol $(15 \mathrm{ml})$ was added to each vial containing BAY SIR to dissolve the material and this was mixed in a commercial food processor with $200 \mathrm{~g}$ of pollen substitute. Control bees were fed the pollen substitute without any BAY SIR. The amount of brood reared and diet consumption was measured weekly during this period.

Studies in which populous free-flying colonies of bees were offered BAY SIR at various. concentrations in a sucrose solution were also conducted. Colonies were offered onc feeding $(3,500 \mathrm{ml}$ of $50 \%$ sucrose $\mathrm{w} / \mathrm{w})$ of syrup containing either 100,150 , or $200 \mathrm{ppm}$ BAY SIR. Each level of BAY SIR was offered to two populous colonies of bees occupying two deep Langstroth hive bodies. In every instance the sucrose solution was consumed in less than 7 days. Dead bee traps were also fitted on each colony and the number of dead bees were counted weekly.

\section{RESULTS AND DISCUSSION}

Bees offered diets containing 1 and $10 \mathrm{ppm}$ BAY SIR reared brood during the 12 week study and the levels were equal to those reared by the bees fed the control diet. Bees offered the diets containing 50 and $100 \mathrm{ppm}$ were not able to rear brood. All units contained eggs throughout the test period but no larvae were observed. When frames containing eggs were removed from these units and placed in free-flying colonies of bees the eggs were either removed or eaten, suggesting that the eggs may not have been viable.

Free-flying colonies of bees fed $100 \mathrm{ppm}$ BAY SIR readily consumed the syrup and after one week the colonies contained only dead pupae and 2- to 3-day-old larvae (which appeared to be healthy). The dead brood as well as the larvae were removed by the bees but 18 days after the initial feeding these colonies again contained healthy sealed brood.

Colonies fed $150 \mathrm{ppm}$ BAY SIR contained only older larvae and sealed brood 6 days after feeding. There were a few cells containing dead pupae and no young larvae were observed. Two weeks after the initial feeding the adult bees had removed all pupae. After 22 days the colonies again contained eggs, larvae of all ages and sealed brood. 
Colonies offered the syrup containing $200 \mathrm{ppm}$ ceased rearing brood. The syrup was fed on 24 July and by 5 August there was no brood present and all bees in the pupal stage were dead. As shown in Fig. 1, the dead brood was present in both sealed and uncapped cells and the resulting spotty brood mimicked the brood pattern seen in colonies suffering from American foulbrood disease. The remains of all pupae were removed by the bees before 12 August when no active brood rearing was evident. Normal brood rearing resumed by 27 August when both colonies contained sealed brood, eggs and larvae of all ages. The dead bee trap collections of adult bees on all treatments showed no increase in «normal» adult mortality during the study.

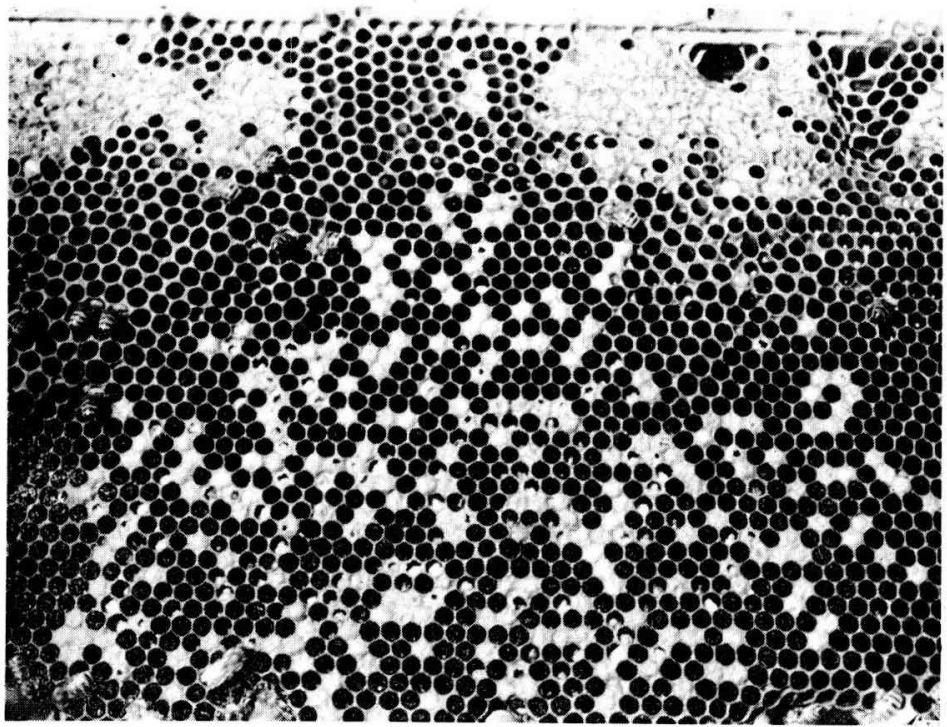

FIG. 1. - Typical dead brood in free-flying colonies of honey bees fed Bay Sir at 100, 150, or $200 \mathrm{ppm}$

These «preliminary» results suggest that feeding chitin synthesis inhibitors such as BAY SIR should be evaluated as a potential control material against $V$. jacobsoni and Tropilaelaps clareae since a complete break in the brood cycle, especially during the active season could result in a large reduction of the mite population and perhaps enhance the activity of presently used acaricides. In the case of $T$. clareae this break in brood cycle may be adequate to eliminate the mites (WoYke, 1985). 


\section{RESUME \\ ACTION SUR L'ABEILLE (APIS MELLIFERA L.) \\ D'UN INHIBITEUR DE LA SYNTHESE DE LA CHITINE DES INSECTES}

L'inhibiteur de la synthèse de la chitine des insectes, BAY SIR 8514, provoque l'arrêt de la production du couvain dans des colonies d'abeilles encagées et des colonies de plein air. L'élevage du couvain a été temporairement arrêté pendant 2 à 3 semaines selon la teneur en BAY SIR. La production normale de couvain a repris après l'arrêt du traitement. Ce traitement peut fournir un moyen de lutte contre l'acarien parasite de l'abeille, Varroa jacobsoni, qui ne se reproduit que dans les cellules de couvain operculé qui renferment des larves âgées ou des nymphes.

\section{ZUSAMMENFASSUNG}

\section{DIE WIRKUNG EINES INSEKTENCHITIN-SYNTHESEHEMMERS AUF HONIGBIENEN}

Es wurde gezeigt, daß ein Insekten-Chitinsynthesehemmer, BAY-SIR 8514, die Bruterzeugung sowohl in gekäftigten wie in freifliegenden Bienenvölkern unterbricht. Die Aufzucht von Brut wurde zeitweilig für eine Periode von zwei bis drei Wochen verhindert, abhängig von der Menge des BAY SIR. Nach Beendigung der Behandlung wurde eine normale Bruterzeugung wieder aufgenommen. Diese Behandlung könnte eine gewisse Kontrolle der parasitischen Bienenmilbe, Varroa jacobsoni, ermöglichen, die sich nur in verdeckelten Brutzellen mit Larven oder Puppen fortpflanzt.

\section{REFERENCES}

Herbert E.W., Jr., Shimanuki H., 1980. - An evaluation of seven potential pollen substitutes for honey bees. Amer. Bee J., 120, 349-350.

Ritter W., 1981, - Varroa disease of the honeybee Apis mellifera. Bee World, 62, 141-153.

TAYLOR O.R., 1977. - The past and possible future spread of Africanized honey bees in the Americas. Bee World, 58, 19-30.

Woyke J., 1985. - Tropilaelaps clareae, a serious pest of Apis mellifera in the tropics, but not dangerous for Apiculture in Temperate Zone. Amer. Bee J., 125, 497-499. 